\title{
LYMPHOCYTE SUBPOPULATIONS IN CHILDREN AFTER ALLOGENEIC STEM CELL TRANSPLANTATION
}

\section{SUBPOPULACJE LIMFOCYTÓW PO PRZESZCZEPIENIU ALLOGENEICZNYCH KOMÓREK MACIERZYSTYCH}

\author{
Department of Pediatric Hematology and Oncology \\ Collegium Medicum, Nicolaus Copernicus University, Bydgoszcz
}

S u m m a r y

B a ckground. Allogeneic hematopoietic stem cell transplantation (allo-HSCT) is a method of treatment in a variety of diseases, which involves replacing the recipient's bone marrow by healthy donor stem cells.

$\mathrm{Objective.} \mathrm{The} \mathrm{aim} \mathrm{of} \mathrm{the} \mathrm{study} \mathrm{was} \mathrm{the} \mathrm{analysis} \mathrm{of}$ immune reconstitution in children and adolescents after alloHSCT.

Patients and methods. We analyzed lymphocyte subpopulations in 67 children after allo-HSCT for hematological malignancies and non-malignant diseases. B-cells, T-cells, NK (natural killer cells) and CD4/CD8 ratio were assayed in peripheral blood by flow cytometry using a set of antibodies CD2/CD19, CD3/CD4/CD8, CD3/CD16CD56 labeled with different fluorescent dyes. The tests were performed at 1, 3, 6, 9, 12, 15, 18 and 24 months after the HSCT.
Results. Normalization of the number of lymphocytes occurred rapidly in the population of NK cells; however, significant decrease in the proportion of NK cells was observed at 6 months after HSCT $(p=0.028)$. The recovery of $\mathrm{T}$ cells occurred after 3 months for $\mathrm{CD} 2$ and after 6 months for CD3 cells. Within the B-cell population, a significant delay of reconstitution was observed: CD19 cell percentage exceeded $5 \%(\mathrm{p}<0.001)$ in the ninth month after HSCT, while it was above $10 \%$ afterwards. The normalization of CD4/CD8 ratio was very slow and delayed and did not achieve normal values within 24 months after allo-HSCT.

Conclusions. Reconstitution of the immune system in children after allo-HSCT is the fastest for NK cells. Normal values of T- and B-lymphocytes were reached after 6 and 9 months, respectively. CD4/CD8 ratio is a parameter the normalization of which requires at least two years.

Streszczenie

W stęp. Przeszczepienie allogenicznych komórek krwiotwórczych (allo-HSCT) to metoda terapeutyczna polegająca na zastąpieniu szpiku kostnego biorcy przez komórki hematopoetyczne pochodzące od zdrowego dawcy.

Ce1. Analiza subpopulacji limfocytów u dzieci po przeszczepieniu allogenicznych komórek krwiotwórczych.

Pacjenci i metodyka. Badaniu poddanych zostało 67 dzieci, u których przeprowadzono allo-HSCT z powodu chorób nowotworowych i nie-nowotworowych. We krwi obwodowej badano limfocyty B, T i NK oraz stosunek CD4/CD8 metodą cytometrii przepływowej, stosując zestawy przeciwciał CD2/CD19, CD3/CD4/CD8, CD3/CD16/CD56 wyznakowane różnymi barwnikami fluorescencyjnymi. Badania wykonano w 1, 3, 6, 9, 12, 15, 18 i 24 miesiącu po HSCT.

W yniki. Normalizacja liczby limfocytów nastąpiła najszybciej w obrębie populacji komórek NK, jednak po 6 miesiącach obserwowano znaczne zmniejszanie odsetka tych komórek $(\mathrm{p}=0,028)$. Normalizacja limfocytów $\mathrm{T}$ wystąpiła po 3 miesiącach dla CD2 i po 6 miesiącach dla 
CD3. W obrębie limfocytów B stwierdzono istotne opóźnienie rekonstytucji: dopiero w 9 miesiącu odsetek komórek CD19+ przekroczył 5\% ( $<<0,001)$, a w kolejnych punktach czasowych wynosił powyżej 10\%. Rekonstytucja odsetka CD4/CD8 była powolna i opóźniona i nie osiągnęła normalizacji w przeciągu 24 miesięcy po allo-HSCT.
W n i o s k i . Rekonstytucja układu immunologicznego u dzieci po allo-HSCT najszybciej przebiega dla komórek NK. Prawidłowe wartości limfocytów T i B osiągane są odpowiednio, po około 6 i 9 miesiącach. Stosunek CD4/CD8 jest parametrem, którego normalizacja wymaga co najmniej 2 lat.

Key words: lymphocyte subpopulation, allogeneic stem cell transplantation, children

Stowa kluczowe: subpopulacje limfocytów, allogeniczny przeszczep komórek macierzystych, dzieci

\section{INTRODUCTION}

Hematopoietic stem cell transplantation (HSCT) is an established approach to treat patients with numerous hematological, oncological, immunological, metabolic and autoimmune disorders [1, 2]. The goal of hematopoietic stem cell transplantation is a transfer of a functional hematopoietic system from donor to host preceded by conditioning regimen with high-dose chemotherapy, sometimes in combination with total body irradiation [3, 4]. The clinical efficacy of HSCT is limited by delayed immune recovery resulting in high relapse rate and infectious complications [5]. A normal reconstitution of the immune system is an important issue for the control of infection, establishment of tolerance, and mediation of graftversus-leukemia (GVL) effects [6]. The reconstitution of different immune cell subsets after an HSCT occurs at different tempos [7]. Immune deficiencies, including cellular and antibody immunity can last for more than a year, resulting in increased susceptibility to infections [2]. Immune reconstitution after HSCT is influenced by many host-, donor- and transplantation-related factors [2].

\section{PATIENTS AND METHODS}

Patients. A total number of 67 children, including 45 males and 22 females, aged 8 months -20 years (median 10 years) were included into the study. All patients underwent allogeneic HSCT for hematological malignancies $(\mathrm{n}=54)$ or non-malignant diseases $(\mathrm{n}=13)$.

Patients were diagnosed for acute lymphoblastic leukemia $(n=31)$, acute myeloid leukemia $(n=19)$, chronic myeloid leukemia $(\mathrm{n}=1)$, myelodysplastic syndrome $(n=1)$, lymphomas $(n=2)$, or non-malignant diseases $(n=13)$. HSCT were performed from matched family donor $(\mathrm{n}=25)$, matched unrelated donor $(\mathrm{n}=38)$, or mismatched unrelated donor $(n=4)$. The stem cell source was bone marrow $(n=30)$ or peripheral blood $(\mathrm{n}=37)$.
Study design. Following lymphocyte subpopulations were tested: lymphocytes B, T, NK (natural killer) and CD4/CD8 ratio. Flow cytometry analysis was performed at 1, 3, 6, 9, 12, 15, 18 and 24 months after HSCT. Not all children were examined at each time point.

Flow cytometry analysis. The absolute numbers of B-, T-, NK and CD4/CD8 lymphocytes were calculated from a total number of PB lymphocytes, the proportion of side scatter/forward scatter lymphocyte region gate and the percentage of positive cells within the gate. The panel of monoclonal antibodies combinations used included: CD2/CD19 or CD5/CD19; CD3/CD4/CD8; CD3-/CD16CD56+. Antibodies were purchased from BD Bioscences (San Jose, CA, USA) and DAKO (Glostrup, Denmark). Briefly, $5 \mu \mathrm{l}$ of appropriate fluorochrome conjugated monoclonal antibodies were added to $50 \mu \mathrm{l}$ of whole EDTA blood and vortexed. The samples were then incubated in the dark room temperature for 15 minutes. Erythrocyte lysis was performed with the use of Erythrocyte-Lysing Reagent Uti-Lyse DAKO (Glostrup, Denmark) after first incubation, $50 \mu 1$ of Erythrocyte-Lysing Reagent A was added to each sample, vortexed and incubated for 10 minutes in dark. The same procedure was repeated with $500 \mu 1$ of Erythrocyte-Lysing Reagent B. Expression of all antigens was analyzed by flow cytometer FACSCanto II BD Bioscencies (San Jose, CA, USA) and data was analyzed using FACSDiva Software BD Bioscencies (San Jose, CA, USA).

Reference values. Results of lymphocyte $\mathrm{B}, \mathrm{T}$ and NK percentages and CD4/CD8 ratio were compared with the reference values [8]. Following values were regarded as normal: 12-24\% for B-lymphocytes, $63.2-$ $77.8 \%$ for T-lymphocytes, $5.4-18.6 \%$ for NK cells, and 1.18-2.65 for CD4/CD8 ratio.

Statistical analysis. Median values and range were shown. Kruskal-Wallis and Mann-Whitney tests were used to compare differences between groups. A pvalue $<0.05$ was considered to be significant. 


\section{RESULTS}

Normalization of the number of lymphocytes occurred rapidly in the population of NK cells, which was observed from the first month after allo-HSCT (Figure 1). However, a significant decrease in the proportion of NK cells was observed from $17 \%$ after the first month to $2.8 \%$ at 24 months after HSCT $(\mathrm{p}=0.028)$. In the meantime, reconstitution of other lymphocyte subpopulations was observed. The normalization of $\mathrm{T}$ cells occurred after 3 months for CD2 and 6 months for CD3 cells. The percentages of T cells remained above $60 \%$ with no significant differences in the consecutive time points $(p>0.05)$. A significant delay in reconstitution was found within the B cell population: CD19 cell percentage exceeded 5\% in the 9th month after HSCT $(p<0.001)$; while in the subsequent time points it was above $10 \%$. A significant delay in reconstitution of $\mathrm{CD} 3+\mathrm{CD} 4+$ has also been observed $(\mathrm{p}<0.001)$, as late as after the 12th months their proportion exceeded only $20 \%$. Normalization of the percentage of $\mathrm{CD} 3+\mathrm{CD} 8+$ cells appeared with $\mathrm{CD} 2$ cell reconstitution in the third month after allo-HSCT. A steady increase of the percentage of CD3+CD8+ cells was observed in the following time points up to $47 \%$ at 18 months after HSCT. As a result, reconstitution of CD4/CD8 ratio was slow and delayed $(\mathrm{p}=0.072)$ and did not achieve normal values within 24 months after allo-HSCT (Figure 1).

\section{DISCUSSION}

Allogeneic HSCT has proved to be an effective treatment in a variety of diseases. However, this procedure is associated with the risk of serious side effects, due to the severe impairment of the immune system induced by this treatment. Conditioning regimen with high-dose chemotherapy or total body irradiation is used to help eradicate the patient disease prior to the infusion of HSC; however, this therapy usually severely impairs immune system. First 100 days after HSCT are characterized by cellular immune deficiency with a reduced value of each subset of lymphocytes [7]. Immunocompromised patients after HSCT are more vulnerable to opportunistic and typical infections and have a higher risk of relapse. The reconstitution of the immune system is usually determined by white blood cell count with differential diagnosis, as well as lymphocyte subpopulations and immunoglobulin concentration including antibody levels.
Fig. 1. Results of reconstitution of $B(A), T(B), N K(C)$ lymphocytes and $C D 4 / C D 8$ ratio $(D)$ Ryc. 1. Poziom rekonstytucji limfocytów B (A), T (B), NK (C) i stosunku CD4/CD8 (D) 
NK cells remains the first subset of lymphocytes to recover after autologous or allogeneic HSCT and possess the highest cytotoxic activity in early posttransplant period [9]. Rapid recovery of NK cells after HSCT - in our study one month - is based on an expansion of the cytokine-producing CD56bright NKcell subset. This early expansion of CD56bright NK cells gradually declines; however, it may persist for a year [7]. Our study has shown that the number of NK cells significantly decreases over the time.

The count of B-lymphocytes in our group of children and adolescents has returned to normal values at 6-9 months after allo-HSCT. Bosch et al. also observed intermediate recovery for B-cells, which was faster for naive than memory B-cells (CD5+ vs CD5cells) [10]. Corre et al. reported expansion of CD19+/CD5+ lymphocytes just after three months and a persisting defect of memory $\mathrm{B}$ cells in adult patients [11]. According to Heining et al., CD19-positive Bcells were normalized after a year in most adult patients [12].

Long-term imbalance between recovery of two major T-cell subsets, helper T-cells (CD3+CD4+) and suppressor/cytotoxic $\mathrm{T}$-cell $(\mathrm{CD} 3+\mathrm{CD} 8+)$ remains a well-known phenomenon [5]. Initial recovery of the Tcell compartment relies on peripheral expansion of memory $\mathrm{T}$ cells, driven by cytokines and the presence of alloreactive antigens, before the production of naive $\mathrm{T}$ cells in the thymus starts. This is especially true for CD4+ T-cells that reconstitute later than CD8+ T-cells and rely more on thymic production of naive $\mathrm{T}$ cells after HSCT, leading to an inversion of the CD4/CD8 ratio [7]. Our results confirm this hypothesis. Although the normalization of $\mathrm{T}$ cell occurred after 3 months for $\mathrm{CD} 2$ and 6 months for CD3, a significant delay in reconstitution of helper T-lymphocytes CD3+CD4+ was shown, which resulted in slow and delayed reconstitution of CD4/CD8 ratio over 24 months.

In conclusion, on the basis of the assessment of lymphocytes subsets, we have shown that immune reconstitution in children and adolescents after alloHSCT has occurred at different rates. Although appropriate level of NK cells was achieved by one month after HSCT, the percentages of CD19+, CD3+, $\mathrm{CD} 2+$ lymphocytes and CD4/CD8 ratio indicated a delayed reconstitution. Allogeneic HSCT offers the opportunity for treatment of patients with malignant and non-malignant disorders; however, delayed immune reconstitution and disease relapse remain significant limitations for its application.
Understanding the causes of hampered immune restoration provides the rationale to develop powerful immunotherapies.

\section{REFERENCES}

1. De Lalla C, Rinaldi A, Montagna D, Azzimonti L, Bernardo ME, Sangalli LM, Paganoni AM, Maccario R, Di Cesare-Merlone A, Zecca M, Locatelli F, Dellabona $\mathrm{P}$, Casorati G. Invariant NKT cell reconstitution in pediatric leukemia patients given HLA-haploidentical stem cell transplantation defines distinct CD4+ and CD4subset dynamics and correlates with remission state. $J$ Immunol 2011;186:4490-4499

2. Bae KW, Kim BE, Koh KN, Im HJ, Seo JJ. Factors influencing lymphocyte reconstitution after allogeneic hematopoietic stem cell transplantation in children. Korean J Hematol 2012;47:44-52

3. Fry TJ, Mackall CL. Immune reconstitution following hematopoietic progenitor cell transplantation: challenges for the future. Bone Marrow Transplant 2005;35:53-57

4. Bemark M, Holmqvist J, Abrahamsoon J, Mellgren K. Translational Mini-Review Series on B cell subsets in disease. Reconstitution after haematopoietic stem cell transplantation - revelation of B cell developmental pathways and lineage phenotypes. Clin Exp Immunol 2011;167:15-25

5. Kalwak K, Gorczyńska E, Toporski J, Turkiewicz D, Slociak M, Ussowicz M, Latos-Grazyńska E, Król M, Boguslawska-Jaworska J, Chybicka A. Immune reconstitution after haematopoietic cell transplantation in children: immunophenotype analysis with regard to factors affecting the speed of recovery. Brit J Haematol 2002;118,74-89

6. Triplett BM, Horwitz EM, Iyengar $\mathrm{R}$, Turner $\mathrm{V}$, Holladay MS, Gan K, Behm FG, Leung W. Effects of activating NK cell receptor expression and NK cell reconstitution on the outcomes of unrelated donor hematopoietic cell transplantation for hematologic malignancies. Leukemia 2009;23:1278-1287

7. Seggewiss R, Einsele H. Immune reconstitution after allogeneic transplantation and expanding options for immunomodulation: an update. Blood 2010;115:38613868

8. Tosato F, Bucciol G, Pantano G, Putti MC, Sanzari MC, Basso G, Plebani M. Lymphocyte subsets reference values in childhood. Cytometry 2014 Aug 6. doi: 10.1002/cyto.a.22520. [Epub ahead of print]

9. Scheid C, Pettengell R, Ghielmini M, Radford JA, Morgenstern GR, Stern PL, Crowther D. Time-course of the recovery of cellular immune function after high-dose chemotherapy and peripheral blood progenitor cell transplantation for high-grade non-Hodgkin's lymphoma. Bone Marrow Transplant 1995;15:901-906

10. Bosch M, Dhadda M, Hoegh-Petersen M, Liu Y, Hagel LM, Podgorny P, Ugarte-Torres A, Khan FM, Luider J, Auer-Grzesiak I, Mansoor A, Russell JA, Daly A, Stewart DA, Maloney D, Boeckh M, Storek J. Immune 
Reconstitution after antithymocyte globulin-conditioned hematopoietic cell transplantation. Cytotherapy 2012;14:1258-1275

11. Corre E, Carmagnat M, Busson M, de Latour RP, Robin M, Ribaud P, Toubert A, Rabian C, Socié G. Long-term immune deficiency after allogenic stem cell transplantation: B-cell deficiency is associated with late infections. Hematologica 2010;96:1025-1029

12. Heining C, Spyridonidis A, Bernhardt E, SchulteMönting J, Behringer D, Grüllich C, Jakob A, Bertz H, Finke J. Lymphocyte reconstitution following allogeneic hematopoietic stem cell transplantation: a retrospective study including 148 patients. Bone Marrow Transplant 2007;39:613-622
Address for correspondence:

prof. dr hab. Jan Styczyński

Katedra Pediatrii, Hematologii i Onkologii

Collegium Medicum

Uniwersytet Mikołaja Kopernika

ul. Curie-Skłodowskiej 9

85-094 Bydgoszcz

e-mail: jstyczynski@cm.umk.pl

Tel: +52 5854860

Received: 27.08.2014

Accepted for publication: 4.11.2014' 